\title{
Feasibility Study of Shallot Production in Financial Aspect in Central Lampung (Case study : Kota Gajah)
}

\author{
Dian Fajarika $^{1}$, Rizqa Ula Fahadha ${ }^{1}$, Intan Mardiono ${ }^{1}$, Nur Miswari ${ }^{1}$ \\ ${ }^{1}$ Industrial Engineering Department, Institut Teknologi Sumatera, Lampung Selatan, Lampung \\ dian.fajarika@ti.itera.ac.id
}

\begin{abstract}
Shallot is superior vegetable commodity in which the demand has a tendency to increase. The growth of demand for commodity is in line with the growth of population in Indonesia. Shallot is included in 7 (seven) basic foodstuffs targeted by Ministry of Agriculture in Indonesia. The need of shallot is supplied by Central Java, East Java, West Java and West Nusa Tenggara. Shallot commodities in Indonesia heavily depend on the season, the government makes a regulation about shallot import for maintaining stability of price. To anticipate the occurrence of imports, the government is focused on inviting local governments to create a farming center of shallot. Lampung Province is one of the provinces that has suitable natural resources for shallot farming. The purpose of this research is to analyze the financial feasibility of shallot farming development based on NPV (Net Present Value), Net B/C (benefit/cost), IRR (Internal Rate Return), and payback period criteria. The financial feasibility analysis through the calculation of cost and benefit components obtained from shallot business and investment criteria to determine the level of feasibility in quantitative terms. The result showed that NPV is IDR. $16,747,507.38$, Net B/C 1.45 , IRR for 4 period is $66.03 \%$ and payback period is 3.58 .
\end{abstract}

Keywords: feasibility study, farming, shallot, financial aspect

\section{Introduction}

Shallot is a vegetable commodity are very used as seasoning in Indonesia. These commodities became the primary seasoning in every cuisine of Indonesia. Besides that, shallots are also needed in other countries, especially in Asia. Shallot production is a priority of the Ministry of Agriculture in the horticulture development program. Shallots are included in the 2015-2019 Strategic Plan for the development program of 7 (seven) strategic staples from the Ministry of Agriculture in addition to rice, corn, soybeans, sugar (sugar cane), beef, and chili (Ministry of Agriculture, 2015). The average consumption of shallots per capita rose from 0.520 ounces per week in 2015 to 0.542 ounces per week in 2016. By calculation of the amount of the per capita, consumption of shallot reached 880 tons in 2016. Shallot production reached 1.08 million tons divided for consumption, seed and export. However, in certain seasons Indonesia still had to import shallots as much as 17,429 tons in 2015 (Data Center and Agricultural Information, 2016). Prices of shallots tend to fluctuated. In the harvest season, the price ranges from Rp. 15,000 - Rp. 18,000 per kilogram, but in certain seasons the price of shallots is up to Rp. 50,000 per kilogram (Bahar, 2015). This fluctuation due to the shallot harvest season which is 
different in the dry season shallot has good productivity, but during the rainy season the amount of harvest decreases.

The government, through the Ministry of Agriculture, hopes for an expansion of shallot fields outside Java to increase the supply of shallots in Indonesia and to maintain the stability of price. One area outside Java island which was developed for the shallot center is the province of Lampung. The reason for choosing Lampung as a center for shallot farming is the land still quite extensive, sufficient labor and a source of natural fertilizer which is still widely found in Lampung. Together with the Lampung Agriculture Office, the Ministry of Agriculture has launched several assistance programs for the development of the shallot central production area. Assistance provided in the form of seeds, fertilizer and various training to improve the skills of farmers. The Lampung area developed for shallot production is in South Lampung, East Lampung and Central Lampung. In this study taking a sample of areas that have been growing shallots continuously, namely in Kota Gajah sub-district. Kota Gajah subdistrict is one area in South Lampung which has a mission to be the center of shallots (Regional Regulation of Central Lampung , 2012). Since 2015, the Kota Gajah sub-district has planted shallots with a frequency of 2 to 3 times per year. In addition, supported training programs from Bank Indonesia and the Ministry of Agriculture. The business feasibility study carried out in this study in the financial aspect to find out as much as feasible shallot farming with investment criteria in the form of cost determination, profit and loss projection, cash flow analysis, depreciation cost, Internal Rate of Return (IRR), Net Present Value (NPV), analysis of the payback period.

\section{Methods}

\subsection{Preparation}

The research conducted by searching as much information as possible about the development of the function of rice fields into shallot fields. Through a literature study, a review of the implementation of methods that have been used in analyzing the financial feasibility of a business. Study strategic plans related to the development of shallot farming and the demand of shallot in Lampung. Identified various problems related to the development of shallot farming that is used as a consideration when processing a feasibility study in the financial aspect.

\subsection{Collecting primary and Secondary Data}

Primary data was collected by survey and in-depth interviews with several experts. The experts are interviewed included the head of the sub-district, the head of the farmer group in the Kota Gajah Subdistrict, the farmers and other parties related to the management of shallot land. The number of experts is 5 persons who have been planted shallots since 2015. The data collected included the area of shallots, shallot crop cycles, financial data and other variables related to planting activities until the shallot distribution. Secondary data includes topography and geography conditions of Central Lampung land, shallot planting standards and methods used in the analysis of feasibility in financial aspect.

\subsection{Processing Data}

All data from survey are identified to calculate assets (fixed assets), current assets such as production costs, plant maintenance costs and indirect costs (overhead) and depreciation costs. The cost component is used to make the income statement, calculate cash flow, calculate the break event point, and the investment criteria included of Internal Rate of Return, Net Present Value, Benefit Cost Ratio and Pay Back Period.

\section{Investment criteria of NPV}


Note

$$
N P V=\sum_{t=0}^{n} \frac{\mathrm{B}_{\mathrm{t}}-\mathrm{C}_{\mathrm{t}}}{(1+\mathrm{i})^{\mathrm{t}}}
$$

$\mathrm{B}_{\mathrm{t}}:$ benefit in $\mathrm{t}$ year

$\mathrm{C}_{\mathrm{t}}:$ cost in $\mathrm{t}$ year

$\mathrm{t}:$ : year

i : discount rate

n : time of project

NPV is standard that calculate the difference between the present value of the income flow arising from investment. This calculation does not take into account inflation and price changes with the assumption that the in the cost and benefit increase proportionally (Graham \& Harvey, 2001).

\section{Investment criteria of IRR}

Internal Rate Return (IRR) is the maximum interest rate that equates the present value of cash out flow and present value from cash inflows or can restore costs incurred.

$$
I R R=1+\frac{N P V_{1}}{N P V_{1}-N P V_{2}} x\left(i_{1}-i_{2}\right)
$$

Keterangan :

IRR : Internal rate of return

$\mathrm{i}_{1}=$ discount rate that produce NPV positive

$\mathrm{i}_{2}=$ discount rate that produce NPV negatif

$N P V_{1}=N P V$ positive

$N P V_{2}=N P V$ negative

(Kasmir and Jakfar, 2012)

\section{Benefit Cost Ratio}

Defined as the ratio between the amount of annual income discount and the amount of the corresponding cost, which is generated during a certain period.

$$
\operatorname{NET} \frac{\mathrm{B}}{\mathrm{C}}=\frac{\sum_{t=0}^{n} \frac{\mathrm{B}_{\mathrm{t}}-\mathrm{C}_{\mathrm{t}}}{(1+\mathrm{i})^{\mathrm{t}}}}{\sum_{t=0}^{n} \frac{\mathrm{B}_{\mathrm{t}}-\mathrm{C}_{\mathrm{t}}}{(1+\mathrm{i})^{\mathrm{t}}}}
$$

where for benefit $\mathrm{B}_{\mathrm{t}}-\mathrm{C}_{\mathrm{t}}>0$ and for cost $\mathrm{B}_{\mathrm{t}}-\mathrm{C}_{\mathrm{t}}<0$.

(Daneshvar and Kaleibar, 2010, cited by Bosma, 2017)

\section{Pay Back Period}


Note :

$$
\text { Payback period }=\frac{I}{A b} x 1 \text { year }
$$

$\mathrm{I}=$ Investment value

$\mathrm{Ab}=$ net cash in flow that have discount

Pay back period is used to determine the period of return on investment that has been issued by investors.

\subsection{Analyzing criteria of investment}

The analysis is done by comparing the data that has been calculated with the standard criteria that have been determined. By the comparing standard, it took conclusions that the business are feasible or not to be conducted. In addition, the research also measures whether business are feasible based on other aspect that influenced financial aspect like demand, farmer skill and government supporting.

\section{Result}

\subsection{Overview Kota Gajah district}

The condition of the area in Kota Gajah is mostly agricultural areas. Based on the Central Lampung District Regulation No. 01 of 2012 concerning the Regional Spatial Planning of Central Lampung Regency in 2011 - 2031 that the Kota Gajah area is focused on the development of agricultural products and fields for supply foodstuff (Regional Regulation of Central Lampung, 2012)

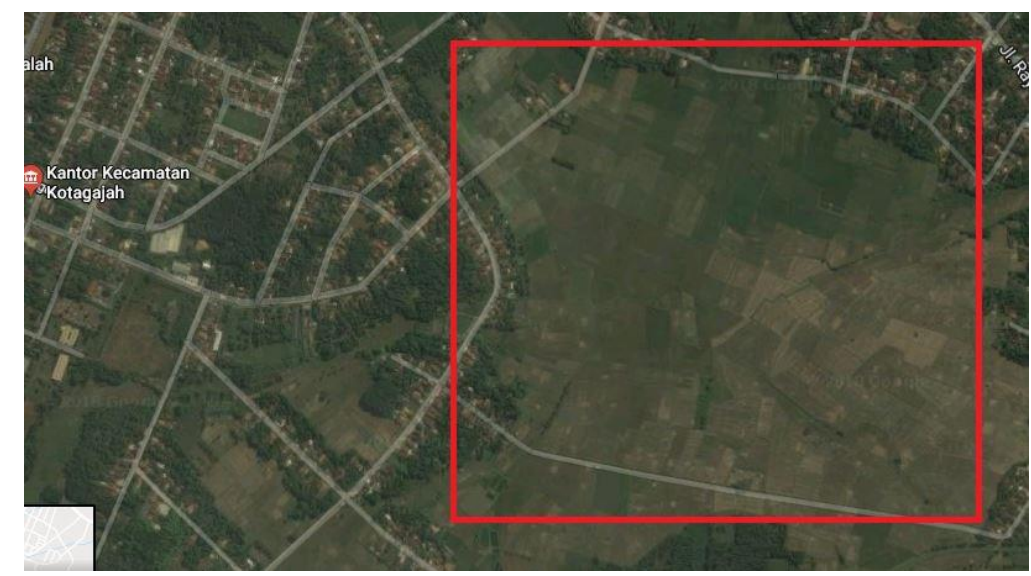

Figure 1. Central development zone of shallot

Agricultural products developed in Gajah City besides rice plants are vegetable crops. Because of fertile soil conditions, flat soil contours, enough water sources and adequacy of wind, it is suitable for shallot fields. One of the field that developed for shallot is in red line. The water sources in Kota Gajah sub-district is depend on irrigation rivers, artificial lake and water from drilled wells. The average land used by each farmer in the City of Gajah is 0.25 Ha. The number of farmers who are now joining in onion planting reaches 30 people. These amount will be increased for support the Kota Gajah district be a central production of shallot.

3.2 Profit loss balancing sheet of shallot farming 
The profit and loss balance sheet calculates all expenses including company tax expenses and income so that the difference between income and expenses is known. The income statement can also be used to measure the level of operational success in business. The calculation begins with calculating the assets owned by farmers. The measurement taken the business of shallot from farmers who have been operated from 2015.

Calculation of assets can be seen in Table 1. Calculation of assets includes equipment and land costs. The asset for land are not counted as costs because the land used is self-owned, the land used is paddy fields which are converted from rice fields to shallot fields and also land that focused for horticulture fields.

Table 1. The assets calculation

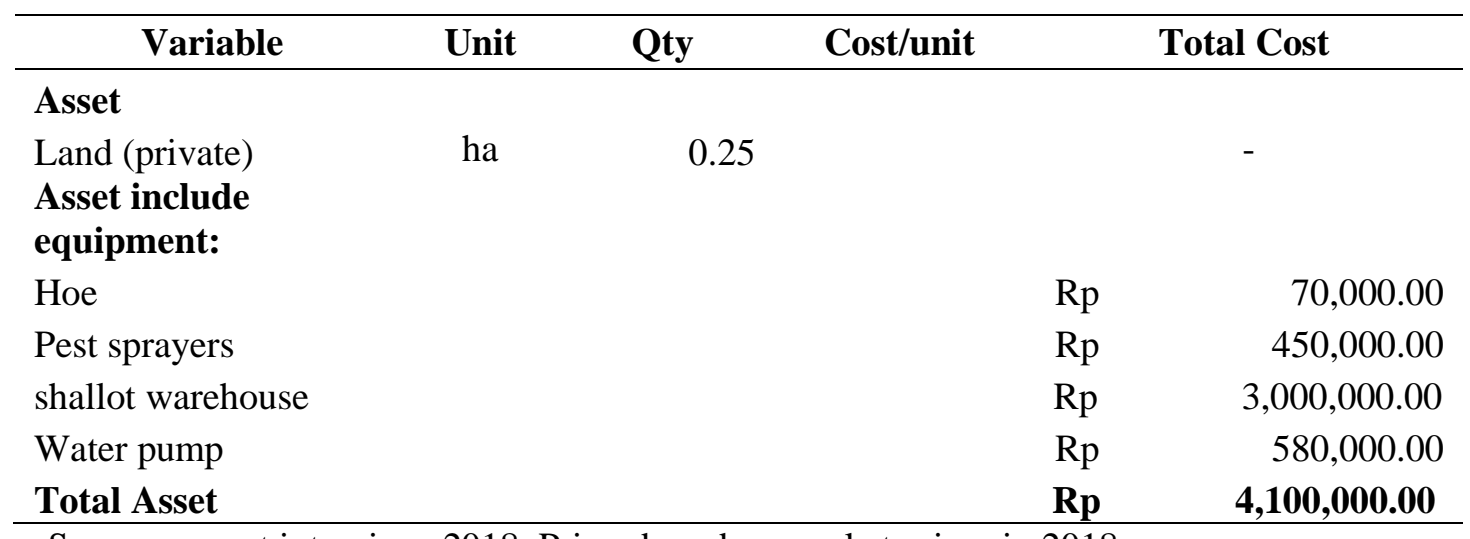

Source: expert interview, 2018. Prices based on market prices in 2018.

Direct costs are calculated from the costs incurred in operations for planting shallot seeds up to the age of 55 days, this is related to the growing period of shallots. Direct costs include production costs, costs for plant maintenance during planting, and costs during the harvest and postharvest. Calculation of direct costs can be seen in Table 2. The production cost calculate all the expenses during planting for example seed cost, fertilizer cost, salary for worker that done the tiling soil, made plant bulbs and planted shallot.

Table 2. Direct cost calculation

\begin{tabular}{lllll}
\hline Variable & Unit & Qty & Cost/unit & Total Cost \\
\hline
\end{tabular}




\begin{tabular}{|c|c|c|c|c|c|c|c|}
\hline \multicolumn{8}{|l|}{$\begin{array}{l}\text { Direct cost } \\
\text { Production cost: }\end{array}$} \\
\hline Seed & & $\mathrm{kg}$ & 350 & $\mathrm{Rp}$ & $15,000.00$ & $\mathrm{Rp}$ & $5,250,000.00$ \\
\hline Organic fertilizer & & sack & 12.5 & $\mathrm{Rp}$ & $40,000.00$ & $\mathrm{Rp}$ & $500,000.00$ \\
\hline ZA fertilizer & & $\mathrm{kg}$ & 50 & $\mathrm{Rp}$ & $12,000.00$ & $\mathrm{Rp}$ & $600,000.00$ \\
\hline Urea Fertilizer & & kg & 23 & $\mathrm{Rp}$ & $25,000.00$ & $\mathrm{Rp}$ & $575,000.00$ \\
\hline $\begin{array}{l}\text { Triple Super } \\
\text { Fertilizer }\end{array}$ & Phospate & $\mathrm{kg}$ & 50 & $\mathrm{Rp}$ & $5,000.00$ & $\mathrm{Rp}$ & $250,000.00$ \\
\hline KCL Fertilizer & & $\mathrm{kg}$ & 30 & $\mathrm{Rp}$ & $7,000.00$ & $\mathrm{Rp}$ & $210,000.00$ \\
\hline Dolomite & & $\mathrm{kg}$ & 350 & $\mathrm{Rp}$ & $1,500.00$ & $\mathrm{Rp}$ & $525,000.00$ \\
\hline Pesticide & & & 1 & $\mathrm{Rp}$ & $1,100,000.00$ & $\mathrm{Rp}$ & $1,100,000.00$ \\
\hline tilling soil cost & & day & 1 & $\mathrm{Rp}$ & $60,000.00$ & $\mathrm{Rp}$ & $60,000.00$ \\
\hline Plant bulbs cost & & $\begin{array}{l}\text { day/5 } \\
\text { peoples }\end{array}$ & 7 & $\mathrm{Rp}$ & $300,000.00$ & $\mathrm{Rp}$ & $2,100,000.00$ \\
\hline planting cost & & day & 1 & $\mathrm{Rp}$ & $120,000.00$ & $\mathrm{Rp}$ & $120,000.00$ \\
\hline Irigation cost & & activity & 1 & $\mathrm{Rp}$ & $250,000.00$ & $\mathrm{Rp}$ & $250,000.00$ \\
\hline fuel cost & & liter & 10 & $\mathrm{Rp}$ & $5,150.00$ & $\mathrm{Rp}$ & $51,500.00$ \\
\hline Subtotal & & & & & & $\mathbf{R p}$ & $11,591,500.00$ \\
\hline
\end{tabular}

Source : expert interview, 2018. Prices based on market prices in 2018.

Table 3. Direct cost calculation con't

\begin{tabular}{|c|c|c|c|c|c|c|}
\hline \multirow{2}{*}{$\begin{array}{l}\text { Variable } \\
\text { Caring plants cost: }\end{array}$} & \multirow[t]{2}{*}{ Unit } & \multirow[t]{2}{*}{ Qty } & \multicolumn{2}{|c|}{ Cost/unit } & \multicolumn{2}{|c|}{ Total Cost } \\
\hline & & & & & & \\
\hline Applying pesticide cost & times & 7 & $\mathrm{Rp}$ & $60,000.00$ & $\mathrm{Rp}$ & $420,000.00$ \\
\hline pesticide cost & set & 1 & $\mathrm{Rp}$ & $300,000.00$ & $\mathrm{Rp}$ & $300,000.00$ \\
\hline Irrigation cost during planting & times & 1 & $\mathrm{Rp}$ & $250,000.00$ & $\mathrm{Rp}$ & $250,000.00$ \\
\hline Subtotal & & & & & $\mathbf{R p}$ & $970,000.00$ \\
\hline $\begin{array}{l}\text { Harvesting } \\
\text { postharvesting cost: }\end{array}$ & & & & & & \\
\hline Harvesting Cost & $\begin{array}{l}\text { Day/10 } \\
\text { peoples }\end{array}$ & 10 & $\mathrm{Rp}$ & $50,000.00$ & $\mathrm{Rp}$ & $500,000.00$ \\
\hline Fumigation & kali & 3 & $\mathrm{Rp}$ & $50,000.00$ & $\mathrm{Rp}$ & $150,000.00$ \\
\hline Packing sack & pcs & 100 & $\mathrm{Rp}$ & $1,200.00$ & $\mathrm{Rp}$ & $120,000.00$ \\
\hline Subtotal & & & & & $\mathbf{R p}$ & $650,000.00$ \\
\hline Total Direct Cost & & & & & $\mathbf{R p}$ & $13,211,500.00$ \\
\hline
\end{tabular}

Source: expert interview, 2018. Prices based on market prices in 2018.

Indirect costs are calculated from costs incurred during the planting process until postharvest but did not directly affected the production of shallots. Indirect costs include transportation costs postharvest, storage costs before sale, equipment depreciation costs and costs for storage warehouse maintenance.

Table 4. Overhead cost calculation

\begin{tabular}{lllll}
\hline Variable & Unit & Qty & Cost/unit & Total Cost \\
\hline
\end{tabular}




\begin{tabular}{|c|c|c|c|c|c|c|}
\hline \multicolumn{7}{|l|}{ Overhead cost } \\
\hline Transportation cost & freq & 1 & $\mathrm{Rp}$ & $100,000.00$ & $\mathrm{Rp}$ & $100,000.00$ \\
\hline Depreciation cost & period & 1 & $\mathrm{Rp}$ & $352,000.00$ & $\mathrm{Rp}$ & $352,000.00$ \\
\hline $\begin{array}{l}\text { Warehouse } \\
\text { maintenance cost }\end{array}$ & period & 1 & $\mathrm{Rp}$ & $250,000.00$ & $\mathrm{Rp}$ & $250,000.00$ \\
\hline Drying cost & period & 1 & $\mathrm{Rp}$ & $500,000.00$ & $\mathrm{Rp}$ & $500,000.00$ \\
\hline Total Overhead cost & & & & & $\mathbf{R p}$ & $1,202,000.00$ \\
\hline
\end{tabular}

Source: expert interview, 2018. Prices based on market prices in 2018.

Total direct costs, indirect costs and assets are calculated as expenses. This cost will be calculated by the total income to known the difference which is the profit or loss obtained by the farmer. Revenue from planting shallots included the number of shallots that can be harvested either for consumption or for seeds. Most of shallots in the Kota Gajah produced for seeds and have been sold to other regions. Calculation of the percentage of shallot that successfully harvested for seeds compared for consumption is 50\% of the yield (Expert Interview, 2018). The price of shallots for seeds follow the price of shallots for consumption. In this study the price of shallots was taken at the lowest price of Rp. 15,000.00. The price of shallots that apply in the market ranges from Rp. 15,000 - 40,000 / kg (Central Bureau of Statistics, Ministry of Trade, 2018).

Table 5. Profit or loss calculation

\begin{tabular}{|c|c|c|c|c|c|c|}
\hline \multirow{2}{*}{$\begin{array}{l}\text { Variable } \\
\text { Total Cost }\end{array}$} & \multirow{2}{*}{ Unit } & \multirow{2}{*}{ Qty } & \multicolumn{2}{|c|}{ Cost/unit } & \multicolumn{2}{|c|}{ Total Cost } \\
\hline & & & & & $\mathbf{R p}$ & $18,513,500.00$ \\
\hline \multicolumn{7}{|l|}{ Income/Benefit } \\
\hline Shallot for consumption & $\mathrm{kg}$ & 900 & $\mathrm{Rp}$ & $15,000.00$ & $\mathrm{Rp}$ & $13,500,000.00$ \\
\hline Shallot for seed & $\mathrm{kg}$ & 900 & $\mathrm{Rp}$ & $15,000.00$ & $\mathrm{Rp}$ & $13,500,000.00$ \\
\hline Income non operational & & & & & $\mathrm{Rp}$ & - \\
\hline Total Income & & & & & $\mathrm{Rp}$ & $27,000,000.00$ \\
\hline Profit (Income - cost) & & & & & $\mathbf{R p}$ & $8,486,500.00$ \\
\hline
\end{tabular}

Calculation of profit or loss is carried out after all direct costs, indirect costs and all expenses are calculated. In Table 5 can be seen that the profit and loss balance calculation produces positive results. This is meaning that the total income is still greater than the cost incurred. Using the lowest price of shallots Rp. $15.000 / \mathrm{kg}$, its prove that this shallot business is profitable for farmers.

\subsection{Calculation of cashflow}

Cashflow calculation to calculate the amount of cash in flow and the amount of cash out flow. With cashflow calculation, it can be known the financial condition of a company in each period. This cashflow calculation can be used to determine the cumulative value of cash for a certain period so that it can be detected whether cashflow shows positive or negative results. It can be seen in Table 6.

Table 6 Cashflow calculation 


\begin{tabular}{cccccc}
$\begin{array}{c}\text { Period } \\
(\mathrm{t})\end{array}$ & Cost & Benefit & Cash Flow & $\begin{array}{c}\text { Kumulatif Cash } \\
\text { Flow }\end{array}$ & ROR/IRR \\
\hline 0 & $18,513,500$ & - & $(18,513,500)$ & $(18,513,500)$ & $0.00 \%$ \\
1 & $14,413,500$ & $27,000,000$ & $12,586,500$ & $(5,927,000)$ & $-32.01 \%$ \\
2 & $14,413,500$ & $27,000,000$ & $12,586,500$ & $6,659,500$ & $23.18 \%$ \\
3 & $14,413,500$ & $27,000,000$ & $12,586,500$ & $19,246,000$ & $46.25 \%$ \\
4 & $14,413,500$ & $27,000,000$ & $12,586,500$ & $31,832,500$ & $56.71 \%$ \\
\hline
\end{tabular}

Cumulative cashflow in this study showed the negative result in zero dan first period. It is tend to positive results in the second period and so on which showed that the company's cash flow in a good condition. In the cashflow calculation, the results of Internal Return Rate were $56.71 \%$ in period- 4 . Based on this data, the shallot farming business can be said that feasible because the IRR is exceeded the bank interest in the local government bank which reaches 13\% (Indonesia Financial Statistics, 2018). The shallot business starts to gain profits after period 2 because it showed a positive IRR result.

\subsection{Investement criteria}

Investment criteria are calculated by determining the MARR (Minimum Acceptable Rate of Return) that applies in the bank in the current year. Calculation of investment criteria can be seen in Table 7 .

Table 7. Calculation of investment criteria

\begin{tabular}{ll}
\hline Invesment criteria & Value \\
& \\
\hline MARR (Minimum Acceptable Rate of & $13.0 \%$ \\
Return) & Rp 16,747,507.38 \\
NPV & $66.03 \%$ \\
IRR & 3.58 \\
PBP (Pay Back Period) & 1.45 \\
Net B/C & \\
& 1 \\
Nt - No & $55.19 \%$ \\
ROR t - ROR 0 & $32.01 \%$ \\
0 ROR 0 & \\
\hline
\end{tabular}

Based on calculation in Table 7, the rate of 13\% that applies according rate in the bank (Indonesian Financial Statistics, 2018). It produced an NPV of Rp. 16,747,507.38, a positive NPV value indicates that the value in the coming year if it is drawn to the current value produces a positive value which means the project can be run. From calculation, the IRR criteria showed a positive value, it also exceeds the discount rate. So the business is feasible to be conducted. For the payback period showed the period is needed to return the investment obtained were 3.58 periods. One period of shallot farming for 3 months. Investors get capital back after the project runs for 3.58 periods or around 11 months if it is without downtime. 


\section{Conclusion}

Based on the research results, it can be seen that the shallot farming in Lampung, especially in the sub-district of Kota Gajah can be run because it is influenced by adequate technical conditions. The Kota Gajah has an areas are focused on the development of horticultural crops. The Kota Gajah subdistrict area also has a flat plain and sufficient water to be used as a center for shallot plants. The results of the financial assessment can be concluded that financially the shallot plant is feasible to run because it meets all investment criteria, namely a positive NPV value, the IRR value that exceeds the bank interest rate and a relatively short payback period.

\section{Acknowledgements}

The authors gratefully acknowledge that the present research is supported by the Head of the Kota Gajah subdistrict and the head of farmer group in Kota Gajah. This research is supported by the Mandiri ITERA Grant and Industrial Engineering major.

\section{References}

[1] Bahar, Syamsul 2015 The Shallot Market Overview. The Ministry of Trade (Indonesia: Jakarta)

[2] Bank of Indonesia 2018 Indonesian Financial Statistic (Indonesia: Jakarta)

[3] Bosma Roel H J 2017 The Financial Feasibility of Producing Fish and Vegetables Through Aquaponics. J. Aquaculture Engineering Vol 76 part B. 146-154

[4] Central Berau Statistics, Ministry of Trade 2018 Prices and Shallot Supply in Main Trade Location (Indonesia:Jakarta). www.ews.kemendag.go.id.

[5] Data Center and Agriculture Information Systems 2016 General Secretary of Agriculture Ministry.The Outlook of Onion (Indonesia: Jakarta)

[6] Graham, J.R \& Harvey,C.R, J 2001. The Theory and Practice of Corporate Finance: Evidence from the Field. Journal of Financial Economics. pp. 187-243

[7] Kasmir and Jakfar 2012 handbookof Feasibility study of Bussiness (Jakarta : Prenadamedia Group)

[8] Ministry of Agriculture 2015 Strategic Plan of the General Directorate of Food Crops 2015 2019 (Indonesia: Jakarta)

[9] Regional Regulation of Central Lampung 2012 District Spatial Planning of Central Lampung in 2011-203. No.1 (Indonesia: Lampung) 